Frank B. Engley, Jr.

Lloyd G. Herman

Robert B. Lindberg

Bertha Y. Litsky

Warren Litsky

Don C. Mackel

George F. Mallison

John D. McCroan

Subcommittee on Disinfection and Sterilization, Committee on Laboratory Standards, American Society for Microbiology

Dieter H. M. Gröschel, Chairman

Willson J. Fahlberg

Lloyd G. Herman
John R. Puleo

Richard Riemensnider

Robert E. Rose

James G. Shaffer

Peter Skaliy

John A. Ulrich

Donald Vesley

William $G$. Walter

Philip G. Passon

William G. Roessler

Earle H. Spaulding

\section{Literatur}

1. Committee on Infections Within Hospitals, AHA: Statement on microbiologic sampling in the hospital. Hospitals 48 (1974) $125-126$.

2. Walter, C. W.: Questions and answers: Role of bacteriologic survey cultures in control of nosocomial infection. $J$. Amer. med. Ass. 229 (1974) 578-579.

3. Stamm, W. W., Mallison, G. F.: Letter to the editor. J. Amer. med. Ass. 230 (1974) 373.

4. Bartlett, R. C. et al.: Control of hospital-associated infections p. 841-857. In: Manual for clinical microbiology, 2nd ed., E. H. Lennette, E. H. Spaulding, J. P. Truant (ed.), American Society for Microbiology, Washington, D. C. 1974.

5. Bartlett, R. C.: Letter to the editor. J. Amer. med. Ass. 230 (1974) 373.

6. Wehrle, P. F.: Letter to the editor. J. Amer. med. Ass. 230 (1974) 373.

\title{
Briefe an die Herausgeber / Letters to the Editors
}

\section{Nomenclature of Penicillins}

Sir - In Infection 2 (1974) 82-94 the compound FL 1060 was mentioned as a new $\beta$-lactam antibiotic. This gives rise to the question why FL 1060 is called a "new penicillin". According to Lund and Tybring (Nature N. Biol. 236 [1972] $135-137)$ it is a matter of " $6 \beta$-amidinopenicillanic acids" and not of " $6 \beta$-acyl-amidopenicillanic acids" as in the classical penicillins. Moreover the results of investigations reviewed until now have shown a lot of facts which contradict classifying FL 1060 as a penicillin:

The antibiotic spectrum differs markedly from that of penicillins. The substance is relatively inactive against cammon penicillin-sensitive bacteria.

Biochemical evidence (Park, J. T., Burman, L.: Biochemical and Biophysical Research Communic. 51 [1973] 863-868 and morphological studies (Melchior, N. H. et al.: Acta Pathologica et Microbiol. Scand. 81 B [1973] 393-407) come to the same conclusion that the mode of action must be quite different from that of penicillins. Strominger et al. (J. Bact. 117 [1974] 578-587) established that this compound differs entirely from the hitherto known penicillins. Greenwood, $D$. and $O^{\prime} G r a d y, F$. are of the same opinion (J. of Clin. Path. 26 [1973] 1-6).

My question to the authors therefore reads as follows: "What is the reason for classifying FL 1060 as a penicillin?"

H. Mielenz, D-7951 Eberhardzell, Mörikeweg 4

Sir - The letter of H. Mielienz, Eberhardzell, West Germany, raises the important point of the precise chemical definition of a penicillin. The terms "penam" and "penicillanic acid" were proposed and defined by Sheehan et al. (1), but it does not seem that the word "penicillin" has ever been formally defined. The common usage, for instance, of the name benzylpenicillin for the chemical 6-phenylacetamidopenicillate does indeed imply that the word "penicillin" means a 6-acylamidopenicillinate, but common usage is no real substitute for a formal definition. We have used "penicillin" in our review (2) in the sense of a penicillinate moiety linked at $\mathrm{C} 6$ to a sidechain through a nitrogen atom.

FL 1060, now given the name mecillinam, is, as we have stated (2) a 6-amidinopenicillinate. It chemically resembles all other penicillins in clinical use in all respects except (a) it has a tertiary as opposed to secondary nitrogen $(\mathrm{N})$ at the 6 position, and (b) that $\mathrm{N}$ lacks a carbonyl substituent. (It is interesting to note that Sheehan (3) has suggested that compounds bearing a tertiary $\mathrm{N}$ at $\mathrm{C} 6$ might be microbiologically inactive.) We have further stated (2) that the mode of action of mecillinam apparently differs from that of other $\beta$-lactam compounds.

Calling mecillinam a penicillin-as has also been done by no less an authority than James T. Park (4) (quoted by the author of the letter)-merely emphasizes the close chemical relationship between this compound and other penam derivatives, and may be justified depending upon one's definition of "penicillin".

We cannot approve of classifying antibiotics by virtue either of their mode of action nor their antimicrobial spectrum; adopting such a system would give rise to far greater anomalies than are produced by a classification in terms of chemical similarity such as we have used (2). If this were the order of the day cephalexin would not be classified as a cephalosporin since it does not cause bacterial lysis, as well as having a different spectrum.

\section{Literature}

1. Sheehan, J. C., Henery-Logan, K. R., Johnson, D. A.: The synthesis of substituted penicillins and simpler structural analogs. VII. The cyclization of a penicilloate derivative to methyl phtalimidopenicillinate. J. Amer. chem. Soc. 75 (1953) $3292-3293$

2. Hamilton-Miller, J. M. T., Brumfitt, $W .:$ Newer $\beta$-lactam antibiotics. Infection 2 (1974) $82-94$.

3. Sheehan, $J$. C.: The chemistry of synthetic and semisynthetic penicillins. Ann. New York Acad. Sci. 145 (1967) $216-221$.

4. Park, J. T., Burman, L.: FL-1060: a new penicillin with a unique mode of action. Biochem. biophys. Res. Comm. 51 (1973) $863-868$.

J. M.T. Hamilton-Miller, W. Brumfitt

The Royal Free Hospital

Pond Street

London NW3 2QG 